зайти Турция? Ответы на все эти значимые глобальные вопросы мы, без сомнений, получим в ближайшее время.

$$
* * *
$$

1. Мадридские принципы. Полный текст [Электронный ресурс] //Ani Armenian Research Centre. Режим доступа: https://www.aniarc.am/2016/04/12/madrid-document-full-russian/.

2. Население Нагорного Карабаха [Электронный ресурс] //ЭтноКавказ. - Режим доступа: http://ethnokavkaz.narod.ru/rnkarabax.html.

3. Мюнхенских соглашений за спиной Армении не будет [Электронный ресурс] //Телеграмм-канал Баграмян26. - Режим доступа: https://t.me/bagramyan26.

4. В Парламент Франции внесен законопроект о признании Республики Арцах [Электронный ресурс] //Телеграмм-канал Armenpress. - Режим доступа: https://t.me/armenpress/42003.

\title{
Ruzanova P.D. \\ Pizzagate: how memes and political discourse evolve in real time
}

Siberian Federal university

(Russia, Krasnoyarsk)

doi:10.18411/spc-01-11-2020-06

idsp: sciencepublic-01-11-2020-06

The Meriam-Webster dictionary tells us that meme is "an amusing or interesting item (such as a captioned picture or video) or genre of items that is spread widely online especially through social media" [1]. Memetic theory shows that repetition of a meme, regardless of whether you think you are 'for' it or 'against' it, helps it spread.

Why is it important to study memes nowadays? First of all, because they shape the political reality. And in our work, we will also prove that sometimes memes create this political reality which may lead to unexpected and undesirable consequences.

The 2016 US presidential campaign between Donald Trump and Hillary Clinton was marked by an unprecedented number of memes. Some memes were connected with the Pizzagate conspiracy theory. This theory appeared in 2016 when the personal email account of John Podesta, Hillary Clinton's presidential campaign manager, was hacked in a spearphishing attack. WikiLeaks published his emails in November 2016 [2]. Proponents of the Pizzagate conspiracy theory falsely claimed the emails contained coded messages that connected several high-ranking Democratic Party officials and one of the US pizza parlours with an alleged human trafficking and child sex ring. According to The New York Times, users of Twitter and 4chan considered the phrase "cheese pizza", which has an abbreviation "pc", among Podesta's messages as child pornography (also abbreviated as "pc") [3].

The theory was laid out on the Godlike Productions forum and appeared on YourNewsWire the next day, quoting a post from the 4chan forum. The story went viral on fake news sites with lightning speed. A SubjectPolitics post claimed that the NYPD had raided Hillary Clinton's home, and a news headline on the Conservative Daily Post said the FBI had "confirmed" the story. The theory rapidly got around on popular mainstream news sites, including Reddit.

Numerous online trolls from among the supporters of Donald Trump flooded Twitter with the hashtag \#pizzagate and created memes and jokes on this theme. Alefantis - the Comet Ping Pong pizzeria's owner - contacted the FBI and asked Reddit and other sites to remove material about his pizzeria allegedly covering up a pedophile network. Reddit decided to prohibit pizzagate posts as breaking community rules.

Thus, it is clear that what started as a malicious internet rumour quickly morphed into a social media trend, and memes played a key role in this process. The hashtag \#pizzagate went viral as thousands of accounts tweeted "evidence" both for and against the story. Many of these tweets originated outside of the United States. 
And here we come to the most worrying aspect of the problem. Shortly after the election, this fictitious online tale made a sinister cross-over into the physical world, as on December 4, 2016, one of the story's followers, a 28-year-old native of North Carolina, Edgar Welch, drove to Washington with an AR-15 assault rifle. He entered the Comet Ping Pong pizzeria, demanding to see the basement (the building does not have one) and fired off three shots. As a result, the walls, a table and a door were damaged. No one was injured. Welch later told the guards that he planned to conduct his own investigation into the involvement of the pizzeria and its employees in pedophilia. He turned himself in to the police after making sure that the pizzeria did not keep children locked up [4].

Therefore, it is obvious that what began as online disinformation had taken a terrible turn. The Pizzagate story is just one illustration of an increasingly important problem of online influence operations, in which memes play a significant role.

Taking everything into consideration, we can draw a number of conclusions:

1. Memes are often used for political purposes not only shaping but also creating the political reality and the world community has to pay special attention to this.

2. Countering this malicious practice is vital. Such efforts require the engagement of not only governments but also the various Internet platforms. Working together, these actors can minimize the risk of fake news and other influence operations.

$$
* * *
$$

1. Merriam-Webster online dictionary [Electronic resource]. - Access mode: https://www.merriamwebster.com/dictionary/meme.

2. Gilling J. How Pizzagate went from fake news to a real problem for a D.C. business [Electronic resource] // POLITIFACT. - December 5, 2016. - Access mode: https://web.archive.org/web/20161206173112/ http://www.politifact.com/truth-o-meter/article/2016/dec/05/how-pizzagate-went-fake-news-realproblem-dc-busin/.

3. Aisch G., Huang J., Kang C. Dissecting the \#PizzaGate Conspiracy Theories [Electronic resource] // Waybackmachine Internet Archive. - December 10, 2016. - Access mode: https://web.archive.org/web/20161210112745/ http://www.nytimes.com/interactive/2016/12/10/business/media/pizzagate.html.

4. Siddiqui F., Svrluga S. N.C. man told police he went to D.C. pizzeria with gun to investigate conspiracy theory [Electronic resource] // Washingtonpost.com. - December 5, 2016. - Access mode: https://www.washingtonpost.com/news/local/wp/2016/12/04/d-c-police-respond-to-report-of-a-man-witha-gun-at-comet-ping-pong-restaurant/. 